\title{
DIREITO, MORAL E RELIGIÃO NO PÓS-SECULARISMO DE HABERMAS
}

\author{
Juliano Cordeiro da Costa Oliveira ${ }^{1}$
}

\begin{abstract}
Resumo
O artigo debate a relação entre direito e moral em Habermas, a partir de sua proposta de um diálogo entre secularismo e religião, naquilo que denomina de pós-secularismo. Em Habermas, o direito não poderá mais procurar um fundamento na tradição, na religião e na moral. O direito, numa sociedade secularizada e pluralista, preencherá as deficiências da moral, assumindo a função da integração social, outrora exercida pela moral. O direito, ao contrário da moral, tem força de coerção, tornando-se essencial para as comunidades contemporâneas e pluralistas. A coerção, todavia, deve ser legitimada pela deliberação, por meio de uma relação entre a positividade e legalidade do direito, com sua legitimidade discursivamente fundamentada. Para Habermas, as argumentações morais, por mais justas que sejam, devem ser institucionalizadas com o auxílio de meios jurídicos, para terem eficácia nas questões: o ponto de vista moral não mais encontra aqui aplicação imediata em modos de conduta, mas sim através de instituições do direito e da política. Por isso, a moral precisa estabelecer uma conexão com o direito, à medida que este impõe objetivamente um agir conforme a norma. Habermas enfatiza que princípios morais não fundamentam o direito, mas "migram" para o direito, permanecendo, com isso, ligado à comunicação intersubjetiva. A grande tarefa de Habermas é articular uma relação entre o direito secularizado e a moral, de modo que uma instância não seja subordinada à outra, passando a serem vistas como complementares, embora diferenciadas. A relação entre direito e moral ganha, por conseguinte, novos contornos, com a reflexão habermasiana acerca do fenômeno religioso nas sociedades secularizadas, por meio do conceito de póssecularismo, numa tentativa de propor um diálogo entre secularismo e religião na democracia.
\end{abstract}

Palavras-chave: Direito. Moral. Religião. Pós-secularismo.

\section{LAW, MORALS AND RELIGION IN HABERMA'S POST-SECULARISM}

\begin{abstract}
The paper discusses the correlation between law and morals in Habermas, based on his proposal for dialogue between secularism and religion in what he denominates post-secularism. In Habermas, the law no longer seeks its foundation in tradition, religion, and morals. Within a secularized and pluralist society, the law will fulfill the deficiencies of morality, assuming the function of social integration, formerly exercised by morals. Law, in contrast to morality, has the force of coercion, making it essential for contemporary and pluralist communities. However, coercion must be legitimized by deliberation, through a relationship between positivity and legality of the law, and its discursively based legitimacy. For Habermas, moral arguments, however fair they may be, must be institutionalized with the help of legal means, in order to be effective in the matters: the morals point of view no longer finds immediate application hereabouts in forms of conduct, but through institutions of law and politics. Therefore, morality needs to establish a connection with the law, as it objectively imposes an act according to the norm. Habermas emphasizes that moral principles do not base the law, but "migrate" to the law, thus remaining linked to intersubjective communication. Habermas' great task is to articulate a relationship between secularized law and morality, so that one instance is not subordinated to the other, becoming complementary, although differentiated. Hence, the relationship between law and morals takes on new shapes, with the Habermasian reflection on the religious phenomenon in secularized societies, through the concept of postsecularism, in an endeavor to propose a dialogue between secularism and religion in democracy.
\end{abstract}

Keywords: Law. Morals. Religion. Post-secularism.

1 Doutor em Filosofia pela Universidade Federal do Ceará (UFC), com Doutorado Sanduíche pela LudwigMaximilian-Universität (LMU), em Munique, Alemanha. Pós-doutorando pela Universidade Federal do Piauí (UFPI) e Bolsista Capes. Email: julianopesquisa81 @ gmail.com. Orcid: http://orcid.org/0000-0002-0844-6731. 


\section{Introdução}

O direito tornou-se, no pensamento habermasiano, um tema central, principalmente a partir de Direito e democracia, em 1992. Na Teoria do agir comunicativo, de 1981, Habermas ainda não havia refletido temas de sua filosofia política, como Estado democrático de direito, soberania popular e direitos humanos. Com Direito e democracia, ele enfatiza que pretende mostrar “(...) que a teoria do agir comunicativo, ao contrário do que se afirma muitas vezes, não é cega para a realidade das instituições" (HABERMAS, 1997a, p. 11).

A reflexão de Direito e democracia resulta também de um desafio de superar um suposto "déficit democrático" existente no interior da Teoria Crítica (SILVA, 2008), exceção feita aos trabalhos de Franz Neumann e Otto Kirchheimer (REPA, 2008). A preocupação com a fundamentação dos critérios normativos pelos quais se podem julgar processos emancipatórios ou regressivos é uma característica do pensamento habermasiano (REPA, 2008). Com isso, chegamos a um ponto crucial: saber que critérios sustentam a crítica e a que padrões de medida o teórico pode recorrer para criticar fenômenos patológicos e suas causas.

Posto isso, um dos temas fundamentais presentes em Direito e democracia, é a relação entre direito e moral nas sociedades contemporâneas. Aqui, a relação entre direito e moral é pensada na perspectiva da secularização.

Em Habermas, o direito não poderá mais procurar um fundamento na tradição, na religião e na moral. Habermas, seguindo o pensamento pós-metafísico, defende uma fundamentação discursiva do direito, isto é, um critério deliberativo do justo. Para ele (1990), a filosofia continuará fiel às origens metafísicas enquanto defender que a razão cognoscente se reencontra no mundo estruturado racionalmente. Segundo ele, se tal diagnóstico não estiver equivocado, a filosofia, em suas correntes pós-metafísicas e pós-hegelianas, converge para uma teoria da racionalidade procedimentalista.

Portanto, racional não é, como entre os antigos, o ser das coisas, ou, como para os modernos, o constituído pela subjetividade transcendental, ou a ordem das coisas produzida pelo processo de formação do espírito. O pensamento filosófico, ao abandonar sua referência à ideia tradicional de totalidade, perde igualmente sua autodeterminação. Em Habermas, a totalidade passa a ser entendida como categoria pertencente ao mundo vivido e diretamente influenciada pela historicidade e pela pragmática.

Habermas (1990), tendo como pano de fundo a racionalização dos mundos vividos, explica que, nas sociedades arcaicas, os mitos cumpriam de forma paradigmática a função de

\begin{tabular}{|l|l|l|l|l|}
\hline Govista Qialectus & Ano 10 & n. 24 & Setembro - Dezembro 2021 & p. $98-115$ \\
\hline
\end{tabular}


fundar uma unidade explicativa do mundo. Tal ideal seria um contraste com a mentalidade moderna de compreensão de mundo, que se caracteriza por uma atitude reflexiva e crítica em relação à tradição.

A defesa de Habermas de um critério do justo sobre o bem, isto é, de critérios de justiça imparciais, ao invés da defesa de uma determinada concepção de bem particular, parte de sua leitura da modernidade e da defesa de um tipo especial de fundamentação de normas, no contexto de um pluralismo razoável de concepções de vida, num mundo de crentes e não crentes.

Nas sociedades arcaicas, as normas de ação dos homens fundamentavam-se na religião e nas narrativas míticas. Estas monopolizavam a interpretação do mundo, uma vez que constituíam a única fonte de referência para o agir. $\mathrm{O}$ homem moderno, ao contrário, dessacralizou o mundo e assumiu uma existência profana. Na modernidade, o homem experimenta-se como sujeito e fonte autônoma de sentido e ação. Dessa forma, não se justifica mais a fundamentação ontológica de normas morais. Estas tinham como referência unicamente a religião e a tradição. Sociedades modernas, porém, são plurais e essencialmente deliberativas.

Isso significa que a legitimidade das normas tem a ver com a participação dos sujeitos que deliberam sobre as diversas questões. A fundamentação de uma ética pósmetafísica e pós-tradicional é algo construído e justificado discursivamente. Habermas ressalta a necessidade de um novo conceito pós-metafísico de razão, que comporte o diálogo entre tradições iluministas e religiosas na democracia deliberativa, como veremos no decorrer deste artigo. A autoridade do sagrado é substituída, na modernidade, pela autoridade de um consenso discursivamente fundado. O indivíduo tem sua inteligibilidade e legitimação em si mesmo, sem a necessária referência às narrativas míticas e religiosas de outrora.

A modernidade fez com que esferas como a do direito, da ciência, da moral e da arte se tornassem independentes da religião. Tudo isso é consequência do que Max Weber (1986) chamou de o desencantamento do mundo. A humanidade partiu de uma era habitada pelo sagrado e pelo mágico, chegando a um mundo racionalizado, guiado pela técnica e pela ciência. Com a passagem para a modernidade, as categorias pós-convencionais, antes desenvolvidas na filosofia e na teoria política, influenciam também o direito, submetendo-o às pressões de fundamentação associadas à ideia de um acordo racional acerca das normas (HONNETH, 2003).

Assim, o direito, numa sociedade secularizada e pluralista, preencherá as deficiências da moral, assumindo a função da integração social, outrora exercida pela moral. O 
direito, ao contrário da moral, tem força de coerção, tornando-se essencial para as comunidades contemporâneas e pluralistas. A coerção, todavia, deve ser legitimada pela deliberação, por meio de uma relação entre a positividade e legalidade do direito, com sua legitimidade discursivamente fundamentada.

Em Direito e democracia, Habermas expressará, portanto, uma renovada confiança na capacidade do direito de contrabalançar os efeitos patogênicos da economia capitalista e da administração estatal, desde que o direito, como vimos, seja fundamentado no discurso, estabelecendo um elo com a comunicação intersubjetiva, de modo que a legalidade institucional do direito ganhe uma legitimidade comunicativa.

Para Habermas, as argumentações morais, por mais justas que sejam, devem ser institucionalizadas com o auxílio de meios jurídicos, para terem eficácia nas questões: o ponto de vista moral não mais encontra aqui aplicação imediata em modos de conduta, mas sim através de instituições do direito e da política. Por isso, a moral precisa estabelecer uma conexão com o direito, à medida que este impõe objetivamente um agir conforme a norma, por intermédio de ameaças, sanções etc.

A moral não pode mais fundamentar o direito, como nas sociedades tradicionais e pré-modernas; o direito não pode ser simplesmente um espelho da moral. Por outro lado, ele não pode se isolar da moral, caindo num positivismo jurídico, perdendo os vínculos de solidariedade social e a legitimidade comunicativa. Habermas enfatiza que princípios morais não fundamentam o direito, mas "migram" para o direito, permanecendo, com isso, ligado à comunicação intersubjetiva. A grande tarefa de Habermas é articular uma relação entre o direito secularizado e a moral, de modo que uma instância não seja subordinada à outra, passando a serem vistas como complementares, embora diferenciadas. A relação entre direito e moral ganha, por conseguinte, novos contornos, com a reflexão habermasiana acerca do fenômeno religioso nas sociedades secularizadas.

Habermas (2007) explicita como a religião, enquanto saber cultural, deve estabelecer um diálogo com o secularismo e as instituições do liberalismo político, num processo de aprendizagem complementar entre secularismo e religião, que se expressa na ideia habermasiana do pós-secularismo. Ele argumenta que, numa teoria política que trabalha com fundamentos normativos e com as condições de funcionamento de Estados de direito democrático, a oposição unilateral entre secularismo e religião coloca em risco a coesão de uma sociedade multicultural e pluralista. O Estado democrático alimenta-se de uma solidariedade de 
cidadãos que se respeitam reciprocamente como membros livres e iguais de uma comunidade política.

Seria irracional, diz Habermas, colocar de lado as tradições religiosas por considerá-las um resíduo arcaico. Que razão, pergunta ele, impediria as religiões de continuar mantendo potenciais semânticos inspiradores? Habermas defende que as tradições religiosas não são simplesmente irracionais e absurdas. Pelo contrário, as grandes religiões mundiais carregam consigo intuições racionais e momentos instrutivos de exigências legítimas. Todavia, a moral, depois da secularização, perdeu seu papel enquanto instância de integração social, agora realizada pelo direito. Habermas defende que as religiões e seus potenciais semânticos inspiradores são bem-vindos desde que sejam capazes de traduzir suas intuições fundamentais para uma linguagem pública e secular.

Como, enfim, Habermas relaciona e concilia o princípio da comunicação intersubjetiva com o funcionamento e a importância das instituições? Que relevância tem o direito nas sociedades pluralistas e secularizadas? Em que o direito se diferencia da moral, bem como se relaciona com ela? Como Habermas articula a relação entre direito e moral, a partir do problema do diálogo entre secularismo e religião, naquilo que denomina de póssecularismo?

\section{Direito e moral na modernidade secularizada}

Em Direito e democracia, Habermas argumenta que é qualidade específica do direito, diferentemente da moral, a coerção, havendo proximidade entre direito e poder produzido comunicativamente. Para Habermas (1997a), a figura pós-tradicional de uma moral orientada por princípios depende de uma complementação através do direito positivo. Habermas explica que inicialmente podemos falar em "direitos" tanto do ponto de vista moral como do jurídico. Entretanto, ele prefere distinguir o que seria do âmbito exclusivo de cada um.

Por "direito", Habermas entende o moderno direito normatizado, que se apresenta com a pretensão à fundamentação sistemática, à interpretação obrigatória e à imposição. $\mathrm{O}$ direito, na perspectiva habermasiana, não representa apenas uma forma do saber cultural como a moral, pois forma, simultaneamente, um componente importante do sistema, em termos de ação e de eficácia nas soluções dos problemas, interligando-se com a comunicação dos sujeitos. Habermas não pretende legitimar a forma do direito por meio de uma fundamentação 
normativa, mas na perspectiva de uma explicação funcional: trata-se de pensar a relação entre moral e direito no sentido de uma relação sociológica complementar de sentido.

O direito, em Habermas, é enfatizado por ser um sistema de ação, adquirindo eficácia direta nas questões, o que não acontece na moral, uma vez que esta se limita a ser um sistema de saber e de julgamento. A obrigatoriedade de normas jurídicas não se apoia somente na compreensão daquilo que é igualmente bom para todos, mas também nas decisões coletivamente obrigatórias de instâncias que criam e aplicam o direito.

Habermas entende que a moral sofre de uma fraqueza motivacional, porque ela não é capaz de gerar sozinha uma motivação para o agir, uma vez que dela não se obtém uma obrigatoriedade geral como no direito, sendo ela um fim em si mesma. Para Habermas (1997a), o que se questiona na moral não são os princípios que transformam em dever o igual respeito por cada um, a saber, a justiça distributiva, a benevolência com os mais necessitados, a lealdade, a sinceridade etc.

O direito e a moral obedecem ao mesmo princípio discursivo, bem como seguem a mesma lógica de discursos de aplicação e fundamentação, de modo que as regras de argumentação e de universalização, tanto para um como para outro, são as mesmas. Do ponto de vista da fundamentação, diz Habermas, as concepções pós-tradicionais do direito e da moral apresentam as mesmas características estruturais.

Certamente, enfatiza Habermas (2002), os juízos morais nos dizem o que devemos fazer, o que se revela na má consciência que nos "aflige" quando agimos contra nossos discernimentos. Contudo, o discernimento a que se chega discursivamente não assegura nenhuma transferência para a ação. Quando temos consciência do que é moralmente correto fazer, até sabemos que não há qualquer boa razão para agirmos de outra maneira. Isso não impede, porém, diz Habermas (2002), que outros motivos acabem sendo mais fortes. Portanto, há uma necessidade de complementação da moral, apenas fracamente motivada, com o direito coercitivo e positivo.

Por conseguinte, o direito moderno não pode mais procurar um fundamento na tradição, na religião e na moral. Esse aspecto é determinante para o debate sobre o diálogo entre religião e secularismo na democracia, que veremos ao longo deste artigo, quando as intuições religiosas da esfera pública e da sociedade civil devem ser traduzidas para um idioma secular no parlamento. Habermas rompe com a ideia de que o direito se subordina à moral, como em Kant. Segundo ele, as normas jurídicas e morais se complementam entre si, mas não podem ser vistas como subordinadas umas às outras.

\begin{tabular}{|c|c|c|c|c|}
\hline Qevista Dialectus & Ano 10 & n. 24 & Setembro - Dezembro 2021 & p. $98-115$ \\
\hline
\end{tabular}


Para Habermas (1997a), a positivação do direito e a consequente diferenciação entre direito e moral resultam de um processo de racionalização e de secularização a partir da modernidade. Por conseguinte, as questões jurídicas separam-se das morais. Nas instituições, o direito positivo separa-se dos usos e costumes. É certo, pondera Habermas, que as questões morais e jurídicas podem se referir aos mesmos problemas. Por exemplo: como é possível ordenar legitimamente relações interpessoais e coordenar entre si ações, servindo-se de normas justificadas? Como é possível solucionar consensualmente conflitos de ação na base de regras e princípios normativos reconhecidos intersubjetivamente?

Entretanto, apesar de a moral e o direito poderem se referir aos mesmos problemas, eles o fazem de ângulos distintos: a moral pós-tradicional representa apenas uma forma do saber cultural, ao passo que o direito adquire obrigatoriedade institucionalmente: o direito não é apenas um sistema de símbolos, mas também um sistema de ação (HABERMAS, 1997a). Esse é o ponto central a partir do qual o direito adquire uma importância fundamental em Habermas.

Para ele, o desencantamento de imagens religiosas do mundo não trouxe, na modernidade, apenas consequências negativas. Com a secularização, houve uma reavaliação da ideia de validade do direito, à medida que os conceitos fundamentais da moral e do direito são transportados para uma fundamentação pós-convencional, nos termos de uma razão comunicativa.

\footnotetext{
O desencantamento de imagens religiosas do mundo, ao enterrar o 'duplo reino' do direito sagrado e profano, não traz consequiências $[$ sic $]$ apenas negativas; ele também leva a uma reorganização da validade do direito na medida em que transporta simultaneamente os conceitos fundamentais da moral e do direito para um nível de fundamentação pós-convencional. [...] De fato, a positividade do direito pósmetafísico também significa que as ordens jurídicas só podem ser construídas e desenvolvidas à luz de princípios justificados racionalmente, portanto universalistas. (HABERMAS, 1997a, p. 100-101).
}

Logo, é preciso conciliar, num mundo cada vez mais pluralista, a importância da normatividade, com a falibilidade dos princípios carentes sempre de justificação. Em Habermas, o direito possui a particularidade de impor coercitivamente as decisões, característica que a moral não tem. Esta só obtém eficácia, em sociedades complexas, quando é traduzida justamente para o código jurídico. O direito, ao contrário da moral, tem a ver com a imposição das normas institucionais.

A moral, por seu turno, não institucionaliza as decisões que são tomadas pelos sujeitos, uma vez que a aceitabilidade das pretensões universais de validade, na moral, acontece apenas na discussão: ela não traz consigo a força motivadora que permite aos juízos morais se 
tornarem eficazes do ponto de vista prático. Em outros termos, a moral não tem instrumentos que obriguem os sujeitos a seguirem aquilo que foi acordado na deliberação.

À moral resta apenas estabelecer uma relação de complementaridade com o sistema jurídico, tendo em vista a eficácia para a ação. Na perspectiva habermasiana, o direito resolveria as debilidades da moral, porque possui o monopólio da força, ou seja, ele pode "fazer valer" aquilo que foi decidido nas deliberações, instituindo sanções proibidoras de comportamentos desviantes. A moral, ao contrário do direito, institui suas normas apenas tendo como base a consciência de que se deve agir compelido pelo consenso.

No entanto, e aqui se faz a diferença determinante em relação ao direito, a moral não tem instrumentos objetivos para exigir das consciências que elas ajam de certa maneira, isto é, a moral não gera uma obrigatoriedade institucional. Para Habermas, o direito, numa sociedade secularizada e pluralista, preenche as deficiências da moral, assumindo igualmente a função da integração social, exercida outrora pela moral. Habermas (1997b) enfatiza que sua abordagem não almeja configurar, como muitos pensam, uma teoria do direito como tal, e sim, acima de tudo, uma teoria da sociedade, em que o direito tenha uma importância determinante.

Então, as argumentações precisam estar conectadas com o direito como sistema de ação, a fim de que aquilo que foi decidido na deliberação possa ser institucionalizado e posto em prática. As proposições do direito adquirem uma eficácia objetiva para a ação, o que não acontece nos juízos morais, haja vista que estes, como vimos antes, não geram obrigações institucionais ou expectativas de comportamento.

O direito também alivia, dentro das sociedades contemporâneas, os sujeitos singulares do fardo de decidirem o que é justo ou injusto a todo o momento, afastando-se da perspectiva republicana tradicional. O direito moderno proporciona um alívio para os sujeitos, carregando às costas a solução dos conflitos embutidos na ação. O direito diferencia-se da moral também pelo fato de desobrigar os destinatários, a quem se exige o cumprimento das normas, dos problemas da fundamentação, aplicação e implementação de tais normas, que são, por sua vez, transferidas para os órgãos estatais.

O direito moderno tira dos indivíduos o fardo das normas morais e as transfere para as leis que garantem a compatibilidade das liberdades de ação. Estas obtêm sua legitimidade através de um processo legislativo, que, por sua vez, se apoia no princípio da soberania do povo. Com o auxílio dos direitos que garantem aos cidadãos o exercício de sua autonomia política, deve ser possível explicar o paradoxo do surgimento da legitimidade a partir da legalidade. (HABERMAS, 1997a, p. 115).

$\mathrm{Na}$ filosofia política habermasiana, a moral e o direito emergem como dimensões distintas, porém cooriginárias, uma vez que suas especificações básicas são ordenadas uma ao 
lado da outra. Habermas destaca a existência de uma compatibilidade entre direito e moral, de modo que uma ordem jurídica só é legítima quando não contraria os princípios morais (OLIVEIRA, 2004).

Exemplo disso é que o direito não deve estar subordinado à moral numa sociedade secularizada e pluralista, tal qual discutimos antes. Porém, o processo legislativo deve permitir que razões morais "flutuem" para o direito. Este nem deve subordinar-se à moral, como em Kant, nem ser legitimado independentemente dela, caindo num positivismo jurídico. Habermas afirma que a moral não legitima o direito, mas os princípios morais flutuam ou migram para o direito. Esse aspecto é essencial para a proposta habermasiana de um diálogo entre secularismo e religião na democracia.

Rainer Forst (2010) destaca, por exemplo, na mesma perspectiva habermasiana, que a migração das normas morais para o direito não significa que elas constituem um supradireito e que a validade do direito seja uma validade moral. Significa apenas que os princípios do direito são justificados de acordo com o critério da reciprocidade, podendo ser limitados somente por razões que satisfaçam esses critérios. Essa exigência não entra no direito a partir de fora, como no direito natural. São as próprias pessoas que exigem razões para a delimitação de suas formas de vida, que devem ser justificadas, recebendo o assentimento de todos os concernidos, sejam religiosos ou não religiosos.

É interessante, como veremos no decorrer deste artigo, que Habermas defenderá que as religiões, a partir da tradução do idioma religioso para o secular, podem contribuir para a construção das normas, pois elas trabalhariam com intuições que não podem ser desprezadas no debate público, mesmo numa sociedade secularizada. Ou seja, as religiões não fundamentam mais o direito, como nas sociedades tradicionais; contudo elas podem traduzir suas intuições religiosas para uma linguagem pública e secular. É nesse sentido que Habermas diz que a moral não fundamenta o direito, mas princípios morais migram ou flutuam para o direito.

A conexão entre poder comunicativo e direito legítimo faz com que os cidadãos não recorram a seus direitos democráticos exclusivamente como se eles fossem liberdades subjetivas (direitos liberais), mas sim como autorizações legítimas para o emprego público das liberdades comunicativas. Em Habermas, há necessariamente uma interligação entre poder produzido comunicativamente e normatização jurídica, que, por sua vez, deve garantir, ao mesmo tempo, o direito à liberdade comunicativa e o direito de participação dos sujeitos nas deliberações. O direito, portanto, não pode ser simplesmente um espelho da moral, ao mesmo 
tempo em que ele não pode se isolar da sociedade, uma vez que as instituições não podem perder seus vínculos sociais.

Assim, como a religião estabelece, enquanto saber cultural, um diálogo com as instituições e o parlamento? Habermas defende que as religiões possuem intuições morais que podem colaborar nos debates públicos acerca das mais diversas questões, havendo, inclusive, uma virada póssecular em sua filosofia, numa tentativa de propor um diálogo entre religião e secularismo na democracia.

\section{Estado democrático de direito e religião}

Habermas (2007) enfatiza que a constituição do Estado liberal obtém sua legitimação de modo autossuficiente, através de argumentos não dependentes das tradições religiosas nem metafísicas. O direito não mais se subordinará à moral, como vimos antes, a fim de que as matérias passíveis de julgamento objetivo sejam dadas pelo direito secularizado, e não pela moral.

O liberalismo político, na forma de um republicanismo kantiano, o qual Habermas (2007) defende, autointerpreta-se como uma justificação pós-metafísica e não religiosa dos fundamentos normativos do Estado de direito democrático. Tal teoria pertence à tradição de um direito da razão que renuncia às assunções cosmológicas e salvíficas, fortes, dos jusnaturalistas clássicos ou religiosos.

É certo, pondera Habermas (2007), que o direito racional possui raízes religiosas. Porém, a legitimação do direito alimenta-se de fontes que há muito tempo se tornaram profanas. Habermas explica que, diante da religião, o senso comum insiste em fundamentos que são aceitáveis não apenas para os membros de uma comunidade religiosa. Não é à toa que o Estado liberal ainda “(...) desperta nos fiéis a suspeita de que a secularização ocidental poderia ser uma via de mão única, que deixaria a religião à margem" (HABERMAS, 2004, p. 145).

Habermas (2007) argumenta que os fundamentos da legitimação do poder do Estado, neutros em termos de visões de mundo, nasceram de fontes profanas da filosofia nos séculos XVII e XVIII. Contudo, mesmo sob tal premissa, persiste uma dúvida, diz ele, a nível motivacional. A partir do papel de cidadãos do Estado que se autoentendem como autores do direito, e não apenas como destinatários, as pressuposições normativas de integridade do Estado constitucional são mais pretensiosas. 
De cidadãos do Estado que se autoentendem como colegisladores, e não apenas destinatários do direito, as motivações que se esperam não podem ser tratadas da mesma maneira que a obediência a leis coativas: os colegisladores devem assumir seus direitos de comunicação e de participação de modo ativo, não somente no sentido dos interesses próprios, mas também orientados pelo interesse comum. Isso exige uma taxa elevada de motivação que não pode ser imposta apenas legalmente, havendo fatores motivacionais importantes para a democracia que estão para além da instrumentalidade política e da obrigação institucional do voto. Isto é, a ordem liberal depende da solidariedade de seus cidadãos. Seria a religião, nesse sentido, uma esfera de valores indispensáveis, mesmo para uma modernidade secularizada?

Em comunidades liberais, a disposição de ajudar concidadãos estranhos e anônimos, bem como de se sacrificar pelos interesses comuns, pode apenas ser recomendada. Por isso, as virtudes políticas são tão importantes para a sobrevivência de uma democracia, como as motivações dos sujeitos. Para Habermas (2007), isso não quer dizer, no entanto, que o Estado liberal seja incapaz de reproduzir seus pressupostos motivacionais a partir de recursos seculares.

A autocompreensão do Estado de direito democrático formou-se numa tradição filosófica que apela para argumentos públicos e acessíveis a todos. "Ora, a assunção de uma razão humana comum constitui a base epistêmica para a justificação de um poder do Estado secular que independe de legitimações religiosas" (HABERMAS, 2007, p. 135). Dessa forma, o Estado constitucional democrático não apresenta, na perspectiva habermasiana, qualquer fraqueza interna que possa constituir uma ameaça à autoestabilização motivacional democrática. Todavia, isso não significa que o secularismo não deva estabelecer um diálogo com as religiões, num processo de aprendizagem complementar entre secularismo e religião. Por isso, Habermas evita leituras reducionistas que esvaziem qualquer possibilidade de diálogo ou discussão pública com doutrinas religiosas.

\section{A sensibilidade da voz da religião}

Seria irracional, diz Habermas (2007), colocar de lado as tradições religiosas por considerá-las um resíduo arcaico. Que razão, pergunta ele, impediria as religiões de continuar mantendo potenciais semânticos inspiradores? Habermas defende que as tradições religiosas não são simplesmente irracionais e absurdas. Pelo contrário, as grandes religiões mundiais carregam consigo intuições racionais e momentos instrutivos de exigências legítimas.

\begin{tabular}{|l|l|l|l|l|}
\hline Govista Qialectus & Ano 10 & n. 24 & Setembro - Dezembro 2021 & p. $98-115$ \\
\hline
\end{tabular}


Segundo Habermas (2007), as Escrituras Sagradas e as tradições religiosas possuiriam intuições sobre a falta moral e a salvação, sobre a superação salvadora de uma vida tida como sem salvação, as quais são mantidas e interpretadas durante milênios. Portanto, a formação da opinião e da vontade não pode censurar a linguagem religiosa, mesmo havendo a necessidade de uma fundamentação pós-metafísica e discursiva das normas, como defende Habermas.

Para ele (1990), enquanto a linguagem religiosa trouxer consigo conteúdos semânticos inspiradores, que não podem ser jogados fora, a filosofia, mesmo em sua figura pós-metafísica, não poderá desalojar ou substituir a religião; enquanto não se encontrar no meio da fala argumentativa palavras melhores para caracterizar aquilo que as religiões sabem dizer, a existência delas será legítima, mesmo no contexto de um pensamento pós-metafísico.

Habermas insiste, no que diz respeito à política institucional, na distinção entre a fala discursiva secular, a qual pretende ser acessível a todos, e a fala discursiva religiosa, dependente das verdades reveladas. As religiões precisam, no parlamento, traduzir para uma linguagem acessível suas contribuições sobre as questões da vida. Sem essa tradução, o conteúdo das vozes religiosas não consegue entrar nas agendas das instituições.

Habermas argumenta que temos que levar em conta a posição que a religião assume na vida das pessoas crentes: o sujeito piedoso encara sua existência a partir da fé. Esta não é apenas uma doutrina ou conteúdo no qual se crê, mas, igualmente, uma fonte de energia da qual um crente se alimenta a vida inteira.

Para Habermas (2007, p. 146), a ideia segundo a qual todos os cidadãos devem deixar-se conduzir por considerações seculares “(...) não tem nada a ver, em última instância, com a realidade de uma existência conduzida pela fé". O Estado liberal, que protege de igual modo todas as formas religiosas de vida, não pode obrigar os cidadãos religiosos, na esfera pública, a separar estritamente argumentos religiosos e não religiosos. Aos olhos dos crentes, isso pode constituir um ataque às suas identidades pessoais.

O Estado liberal possui, evidentemente, um interesse na liberação de vozes religiosas no âmbito da esfera pública política, bem como na participação política de organizações religiosas. Ele não pode desencorajar os crentes nem as comunidades religiosas de se manifestarem também, enquanto tal, de forma política, porque ele não pode saber de antemão se a proibição de tais manifestações não estaria privando, ao mesmo tempo, a sociedade de recursos importantes para a criação de sentido. (HABERMAS, 2007, p. 148, grifo do autor).

A concepção de justiça dos crentes lhes ensina o que é politicamente correto ou incorreto. Dessa forma, o Estado liberal, que protege as formas de vida dos religiosos mediante

\begin{tabular}{|c|c|c|c|c|}
\hline Qevista Dialeatus & Ano 10 & n. 24 & Setembro - Dezembro 2021 & p. $98-115$ \\
\hline
\end{tabular}


a garantia da liberdade de religião, não pode exigir, ao mesmo tempo, que os crentes fundamentem seus posicionamentos políticos, deixando inteiramente de lado suas convicções religiosas ou metafísicas sobre o mundo. Para Habermas, haveria nisso uma sobrecarga mental psicológica insuportável para os religiosos, prejudicando as necessárias condições simétricas de participação na democracia entre crentes e não crentes.

Ao participarem das discussões públicas, cidadãos religiosos podem reconhecer que a reserva da tradução do idioma religioso para o secular não constitui uma divisão de suas identidades em partes privadas e públicas. O Estado liberal não pode obrigar os cidadãos religiosos, ainda na esfera pública, a separarem estritamente entre argumentos religiosos e não religiosos, sob pena de os religiosos serem tratados como "cidadãos de segunda classe", através de uma forma de "inclusão excludente" (FORST, 2018, p. 212).

Tal exigência apenas poderá ser dirigida aos políticos que assumem mandatos públicos ou pretendem assumir. Eles “(...) são obrigados a adotar a neutralidade no que tange às visões de mundo" (HABERMAS, 2007, p. 145). Portanto, os religiosos devem reconhecer que o princípio do exercício do poder é neutro do ponto de vista das visões de mundo. Eles precisam saber e aceitar que, nas instituições, parlamentos, tribunais e ministérios, apenas contam argumentos seculares. No parlamento, diz Habermas (2007), deve-se retirar da ordem do dia posicionamentos ou justificativas religiosas. Isso não significa que a religião não possa orientar os indivíduos. Entretanto, deve-se traduzir, como explicitamos antes, as intuições religiosas para argumentações seculares no parlamento.

Para Habermas, faz parte das convicções religiosas dos crentes o fato de que eles devem basear suas decisões de acordo com suas convicções religiosas. Eles não podem ver isso como uma opção qualquer entre fazer ou não fazer certas coisas. Do ponto de vista do crente, há um esforço para atingir a completude e a integridade em suas vidas, através da palavra de Deus, do ensino da Torá, dos mandamentos e exemplos de Jesus etc. Isso configura a existência dos crentes, tal qual um todo incluído, bem como a existência social e política.

Habermas (2013) argumenta que o conflito sobre a autocompreensão secular da sociedade não pode ser deslocado apenas para os religiosos. O senso comum não é singular, uma vez que se estabelece numa esfera pública plural. Portanto, os seculares não devem chegar a conclusões nos diversos temas, “(...) antes de dar ouvidos à objeção dos oponentes que se sentem lesados em suas convicções religiosas" (HABERMAS, 2013, p. 16).

Os cidadãos religiosos, na esfera pública, como vimos antes, podem manifestar-se em sua própria linguagem. Do contrário, os concidadãos religiosos, nas deliberações públicas, 
seriam sobrecarregados de modo assimétrico em relação aos secularizados. Entretanto, no parlamento, há a ressalva da tradução do idioma religioso para o secular. O fardo da tradução é compensado pela expectativa normativa, segundo a qual os cidadãos seculares se abrem a um possível conteúdo de validade vindo das religiões. Apesar de não passarem por uma censura na esfera pública, as contribuições religiosas dependem de trabalhos cooperativos de tradução para poderem entrar na pauta de discussão do parlamento.

Contudo, Habermas reforça a ideia de um Estado de direito neutro do ponto de vista das imagens de mundo, pois somente este está preparado para garantir a convivência tolerante entre crentes das mais diversas religiões e não crentes: a crítica ao secularismo não deve "(...) abrir as portas para revisões que venham a anular a separação entre Igreja e Estado" (HABERMAS, 2007, p. 140). Cidadãos justificam, uns perante os outros, seus posicionamentos políticos. Habermas, através de seu pós-secularismo, irá propor uma revisão da ideia clássica de secularização, de modo que as religiões podem colaborar nos debates público, desde que suas intuições sejam traduzidas para uma linguagem pública e secular no parlamento, ao mesmo tempo em que os secularizados não podem a priori ignorar as intuições dos religiosos.

\section{A reviravolta pós-secular: uma dialética da secularização.}

Para Habermas, começa a prevalecer na sociedade pós-secular, e não mais apenas secular, a ideia de que tanto as mentalidades religiosas quanto as seculares precisam modificarse de forma reflexiva, aprendendo as contribuições de uma e de outra para os diversos temas. Nesse sentido, Habermas (2007, p. 126) explica o porquê do termo pós-secular:

A expressão 'pós-secular' foi cunhada com o intuito de prestar às comunidades religiosas reconhecimento público pela contribuição funcional relevante prestada no contexto da reprodução de enfoques e motivos desejados. Mas não é somente isso. Porque na consciência pública de uma sociedade pós-secular reflete-se, acima de tudo, uma compreensão normativa perspicaz que gera conseqüências [sic] no trato político entre cidadãos crentes e não crentes.

No pós-secularismo, impõe-se a ideia de que a modernização da consciência pública abrange, em diferentes fases, tanto mentalidades religiosas como profanas, transformando-as reflexivamente. Habermas argumenta que a secularização cultural e social deve ser entendida como um processo de aprendizagem complementar, que obriga tanto as tradições do Iluminismo quanto as doutrinas religiosas a refletirem sobre seus respectivos limites. A consciência religiosa, por sua vez, precisa assimilar cognitivamente o contato com

\begin{tabular}{|l|l|l|l|l|}
\hline Govista Q Dialectus & Ano 10 & n. 24 & Setembro - Dezembro 2021 & p. $98-115$ \\
\hline
\end{tabular}


outras visões de vida: ela deve abrir-se às premissas do Estado constitucional, que se fundamenta numa moral profana.

A compreensão pluralista da tolerância em sociedades pós-seculares exige dos crentes e não crentes a compreensão razoável de que eles têm de contar com a permanência de um dissenso. A neutralidade, em termos de visões de mundo do Estado secular, garantidora de iguais liberdades éticas para cada cidadão, não diz respeito, contudo, à generalização política de uma visão de mundo secularista. Esse é um aspecto novo no pensamento de Habermas. Ele defende que, embora o caráter secular do Estado seja uma condição necessária, ainda não é algo suficiente.

A expressão pós-secular, tal qual explica Luiz Bernardo Leite Araújo (2013), não é uma alternativa ao horizonte pós-metafísico da modernidade. O pós-secularismo permanece secular a despeito do prefixo pós, correspondendo a uma mudança de mentalidade ou a uma alteração crítica do autoentendimento secularista de sociedades que se tornaram conscientes da persistência da religião, de sua relevante contribuição para a vida política.

A tradução cooperativa de conteúdos religiosos remete a uma ética da cidadania cuja realização depende de enfoques epistêmicos mediante os quais as dissonâncias cognitivas sejam tratadas como desacordos razoáveis entre todas as partes engajadas em processos de aprendizagem complementares. Segundo Habermas, o pensamento pós-metafísico deve adotar uma atitude simultaneamente agnóstica e receptiva diante da religião, que se oponha a uma determinação estritamente secularista das razões publicamente aceitáveis, sem comprometer, entretanto, sua autocompreensão secular.

Habermas (2007) não abdica, como mostramos antes, da autocompreensão secular da modernidade, a qual é derivada da reconstrução racional de uma lógica do desenvolvimento, na qual a racionalização das imagens religiosas de mundo, como processo de aprendizagem, desempenha um papel de considerável relevância. Ele, por outro lado, questiona, sem deixar de estar em consonância com seu projeto teórico, a leitura secularista do processo de modernização. Isso lhe permite salvaguardar a acentuação crítica da posição universalista da razão comunicativa.

O pensamento pós-secular reconhece a importância das tradições religiosas no trato de intuições morais profundas e na articulação daquilo que falta ou que se perdeu, não pretendendo despi-las de possíveis conteúdos racionais nem desvalorizá-las como resíduos arcaicos de uma figura do espírito superada pelas ciências. 
Habermas propõe uma reavaliação da tese tradicional da secularização a partir do questionamento do secularismo ou laicismo como visão de mundo. Habermas (2015, p. 2-3), assim, diferencia o conceito de secular/laico de secularista/laicista, num artigo publicado no jornal La Repubblica:

\begin{abstract}
Aqui eu gostaria de fazer uma distinção entre laico e laicista, entre secular e secularista. A pessoa laica, ou não crente, se [sic] comporta com agnóstica indiferença em relação às pretensões religiosas de validade. Os laicistas, ao contrário, assumem uma atitude polêmica em relação àquelas doutrinas religiosas que (embora cientificamente infundadas) têm grande relevância na opinião pública. Hoje, o secularismo se apoia frequentemente em um naturalismo hard, justificado em termos cientificistas. Pergunto-me se - para os fins da autocompreensão normativa de uma sociedade pós-secular - uma mentalidade laicista hipoteticamente generalizada não acabaria sendo igualmente pouco desejável em comparação com um desvio fundamentalista dos crentes. Na realidade, o processo de aprendizagem deveria ser prescrito não só para o tradicionalismo religioso, mas também para a sua contrapartida secularizada. [...] é preciso que o Estado não reduza preventivamente a complexidade polifônica das diversas vozes públicas. Se, em relação aos seus concidadãos religiosos, as pessoas laicas tivessem que pensar que não podem levá-los a sério como autênticos contemporâneos da modernidade - por causa da sua atitude religiosa, então se deslizaria de volta para o plano do mero modus vivendi e se perderia aquela 'base do reconhecimento' que é constitutiva da cidadania.
\end{abstract}

Habermas, porém, preserva o ganho histórico da secularização das instituições e da separação entre Igreja e Estado, sendo algo, para ele, inegociável e de absoluta importância. No pós-secularismo, o Estado continua sendo neutro em termos de concepção de mundo, mas não seria secularista ou laicista, no sentido de defender uma ideologia que excluísse a religião (ROUANET, 2010). Habermas critica um tipo de visão secularista ou laicista de mundo que coloca as religiões em segundo plano ou as trata como algo puramente irracional e sem valor. Como vimos, as instituições do liberalismo político, tal qual o direito secularizado, não podem ser fundamentadas numa moral, como nas sociedades tradicionais. Ao mesmo tempo, o direito não pode se fechar em si mesmo, ignorando as deliberações dos sujeitos, sejam crentes ou não.

\title{
Conclusão
}

As religiões devem ser capazes de traduzir suas intuições éticas para uma linguagem pública e secular. Os não crentes, por sua vez, não podem negar a priori o potencial semântico e inspirador das religiões, sem estabelecer um diálogo. O pós-secularismo de Habermas é, em realidade, uma dialética da secularização. De um lado, Habermas preserva o ganho secular das instituições, de modo que apenas um estado laico e secular pode manter o pluralismo dos nossos tempos. O estado laico e secular é a-religioso, mas não antirreligioso. Isso não significa cairmos

\begin{tabular}{|c|c|c|c|c|}
\hline Qovista Qialectus & Ano 10 & n. 24 & Setembro - Dezembro 2021 & p. $98-115$ \\
\hline
\end{tabular}


num tipo de laicismo ou secularismo, tal qual uma ideologia, não estabelecendo um diálogo com os religiosos. Estes não podem ser vistos como cidadãos de segunda classe, e sim como sujeitos participantes das deliberações num processo de aprendizagem complementar entre secularismo e religião.

O direito, então, é refletido por Habermas à luz do processo de secularização. O direito, por um lado, como vimos, não pode ser fundamentado a partir de uma tradição, religião ou moral. Ele, portanto, não pode ser simplesmente um espelho da moral. O direito é justificado por Habermas à luz de seu papel de coerção e integração social, mas agora legitimado discursivamente. A moral por si só não tem força de coerção numa sociedade diferenciada, secularizada e pluralista. O direito e a moral, em Habermas, são instâncias complementares, e não podem ser vistas como subordinadas uma a outra. A moral não possui a perspectiva de fazer cumprir aquilo que foi acordado nas deliberações, enquanto o direito, por sua vez, possui a coerção, fazendo valer aquilo que foi acordado nas deliberações.

Ao mesmo tempo, o direito não pode se isolar da sociedade, perdendo os vínculos sociais, tal qual um sistema fechado em si mesmo. Habermas propõe uma relação complementar entre a legalidade do direito e sua legitimidade comunicativa, à luz da relação entre direito e moral, com suas especificidades. Isto também ganha novos contornos com o debate entre secularismo e religião, quando Habermas propõe uma reflexão dialética do iluminismo. Assim, como vimos neste artigo, Habermas reflete a relação entre direito e moral no âmbito de seu póssecularismo.

\section{Referências}

ARAÚJO, L. Apresentação à edição brasileira. In: HABERMAS, J. Fé e saber. São Paulo: Unesp, 2013. p. XIII-XX.

FORST, R. Contextos da justiça: filosofia política para além de liberalismo e comunitarismo. São Paulo: Boitempo, 2010.

FORST, R. Justificação e crítica: perspectiva de uma teoria crítica da política. São Paulo: Unesp, 2018.

HABERMAS, J. Pensamento pós-metafísico: estudos filosóficos. Rio de Janeiro: Tempo Brasileiro, 1990.

HABERMAS, J. Direito e democracia: entre facticidade e validade. Rio de Janeiro: Tempo Brasileiro, 1997a. v. 1. 
HABERMAS, J. Direito e democracia: entre facticidade e validade. Rio de Janeiro: Tempo Brasileiro, 1997b. v. 2.

HABERMAS, J. A inclusão do outro: estudos de teoria política. São Paulo: Loyola, 2002a.

HABERMAS, J. O futuro da natureza humana: a caminho de uma eugenia liberal? São Paulo: Martins Fontes, 2004.

HABERMAS, J. Entre naturalismo e religião: estudos filosóficos. Rio de Janeiro: Tempo Brasileiro, 2007.

HABERMAS, J. Fé e saber. São Paulo: Unesp, 2013.

HABERMAS, J. A minha crítica à razão laicista. La Reppublica. 27 mar. 2015.

HONNETH, A. A. Luta por reconhecimento: a gramática moral dos conflitos sociais. São Paulo: 34, 2003.

OLIVEIRA, M. A. Moral, direito e democracia: o debate Apel versus Habermas no contexto de uma concepção procedimental da filosofia prática. In: APEL, K.-O.; OLIVEIRA, M. A.; MOREIRA, L. (Org.). Com Habermas, contra Habermas: direito, discurso e democracia. São Paulo: Landy, 2004. p. 145-176.

REPA, L. Jürgen Habermas e o modelo reconstrutivo de teoria crítica. In: NOBRE, M. (Org.).

Curso livre de teoria crítica. Campinas: Papirus, 2008. p. 161-182.

ROUANET, S. Habermas e a religião. Revista Tempo Brasileiro: Jürgen Habermas - 80 anos, Laranjeiras, n. 181-182, p. 143-153, 2010.

SILVA, F. Democracia deliberativa. In: NOBRE, M. (Org.). Curso livre de teoria crítica. Campinas: Papirus, 2008. p. 173-197.

WEBER, M. Religião e racionalidade econômica. In: COHN, G. (Org.). Weber: sociologia. 3. ed. São Paulo: Ática, 1986. p. 142-159. 